\title{
Genetic transformation of sweet oranges with the D4E1 gene driven by the AtPP2 promoter
}

\author{
Lísia Borges Attílio(1), Francisco de Assis Alves Mourão Filho(1), Ricardo Harakava(2), Tatiane Loureiro da Silva(1), \\ Luzia Yuriko Miyata $^{(1)}$, Liliane Cristina Libório Stipp ${ }^{(1)}$ and Beatriz Madalena Januzzi Mendes ${ }^{(3)}$

\begin{abstract}
(1)Escola Superior de Agricultura Luiz de Queiroz, Caixa Postal 9, CEP 13418-900 Piracicaba, SP, Brazil. E-mail: lisiaborges@gmail.com, francisco.mourao@usp.br, tatianesilva@usp.br, luziaym@yahoo.com.br, liliane.stipp@gmail.com (2)Instituto Biológico, Avenida Conselheiro Rodrigues Alves, no 1.252, CEP 04014-002 São Paulo, SP, Brazil. E-mail: harakava@biologico.sp.gov.br ${ }^{(3)}$ Centro de Energia Nuclear na Agricultura, Avenida Centenário, no 303, CEP 13400-970 Piracicaba, SP, Brazil. E-mail: bmendes@cena.usp.br
\end{abstract}

\begin{abstract}
The objective of this work was to produce transgenic 'Pêra' and 'Valência' sweet orange plants using the D4E1 gene driven by the Arabidopsis thaliana phloem protein (AtPP2) promoter and to quantify transgene expression in different transformation events. Genetic transformation experiments were carried out with epicotyl segments co-cultivated with Agrobacterium tumefaciens. Six plants from 'Pêra' sweet orange and seven plants from 'Valência' sweet orange were confirmed as different transgenic events by means of the polymerase chain reaction (PCR) and the Southern blot techniques. Transgene expression was quantified using real-time quantitative PCR. D4E1 gene expression levels vary from 5 up to 50 times among different transformation events.
\end{abstract}

Index terms: Citrus sinensis, antimicrobial peptide, tissue-specific promoter.

\section{Transformação genética de laranjas doces com o gene D4E1 dirigido pelo promotor AtPP2}

\begin{abstract}
Resumo - O objetivo deste trabalho foi obter plantas transgênicas de laranja 'Pêra' e 'Valência' por meio do gene D4E1 dirigido pelo promotor Arabidopsis thaliana phloem protein (AtPP2) e quantificar a expressão dos transgenes nos diferentes eventos de transformação. Os experimentos de transformação genética foram realizados com segmentos de epicótilo cocultivados com Agrobacterium tumefaciens. Seis plantas de laranja 'Pêra' e sete plantas de laranja 'Valência' foram confirmadas como distintos eventos transgênicos por meio das técnicas de reação em cadeia da polimerase (PCR) e Southern blot. A expressão dos transgenes foi quantificada por PCR quantitativo em tempo real. Os níveis de expressão do gene $D 4 E 1$ variam de 5 a 50 vezes entre os diferentes eventos de transformação.
\end{abstract}

Termos para indexação: Citrus sinensis, peptídeo antimicrobiano, promotor tecido-específico.

\section{Introduction}

Brazil is the world's largest producer and exporter of frozen concentrated orange juice. It exports $98 \%$ of the juice produced in the country, which represents $85 \%$ of the juice consumed worldwide. The Brazilian citrus industry is directly and indirectly responsible for more than 230,000 jobs in the country (Neves et al., 2010). The primary scion cultivars used in Brazilian orchards are 'Hamlin', 'Pêra', 'Valência', and 'Natal'; therefore, approximately $90 \%$ of the orchards comprise these cultivars, which implies low genetic variability and a contribution to increased vulnerability, especially to diseases (Machado et al., 2010).

Huanglongbing (HLB) is a disease associated with phloem-restricted, Gram-negative bacteria. To date, three species of HLB-associated bacteria were identified: "Candidatus Liberibacter africanus" (CLaf), "Ca. L. asiaticus" (CLas), and " $\mathrm{Ca}$. L. americanus" (CLam). These bacteria were classified according to the continent where they were first identified. The CLam and CLas species are found in Brazil, and the latter is the most frequently observed in the country. The bacteria are transmitted through propagation by infected budwood or by the Diaphorina citri psyllid, which is the disease vector in Brazil (Bové, 2006).

Gene insertion through genetic transformation is an alternative for controlling this disease given the lack of resistance to HLB in the citrus genus, low effective control measures, and rapid disease dissemination (Belasque Júnior et al., 2010). Antimicrobial peptides have been identified in several organisms, from bacteria 
to humans, and they are recognized as key components of the defense system. D4E1 is a synthetic peptide with 17 amino acids and a beta sheet conformation in solution that does not change when interacting with cell membranes (De Lucca et al., 1998); it originates from and operates similarly to cecropins by forming pores in the cell membrane of Gram-positive and Gram-negative bacteria. Tests to evaluate hemolytic activity for $D 4 E 1$ in mammalian cells showed that this peptide has low toxicity at the concentrations used for phytopathogen elimination (Stover et al., 2013).

The expression of synthetic peptides in transgenic plants offers advantages over natural analogs, including greater specificity, efficiency at low concentrations and a smaller size compared with natural peptides, without contamination or toxicity for the transgenic plant tissue; furthermore, it better resists degradation compared with natural cecropin (Cary et al., 2000). Transgenic plants from a Populus tremula L. x P. alba L. hybrid that expressed the $D 4 E 1$ peptide showed a decrease in symptom severity for diseases caused by Agrobacterium tumefaciens and Xanthomonas populi pv. populi (Mentag et al., 2003). The genetic transformation of tobacco with a gene encoding the synthetic antimicrobial peptide D4E1 controlled the growth of Aspergillus flavus and Verticillium dahliae fungi (Cary et al., 2000); whereas the D4E1 gene expression in cotton plants reduced disease symptoms caused by Thielaviopsis basicola (Rajasekaran et al., 2005). In a recent work, Stover et al. (2013) reported excellent results regarding in vitro control by the $D 4 E 1$ peptide of Proteobacteria, which belong to the same family of HLB-associated bacteria ( $\mathrm{Ca}$. Liberibacter spp.). Presumably, the expression of the D4E1 peptide in phloem might be effective for controlling HLB-associated bacteria in citrus.

Several promoters have already been identified for tissue-specific expression, including those that preferentially induce expression in the phloem, such as Citrus sinensis sucrose synthase-1 promoter (CsSUS1p) (Singer et al., 2011), Arabidopsis thaliana phloem protein 2 (AtPP2), C. sinensis phloem protein 2 (CsPP2), A. thaliana sucrose transporter 2 (AtSUC2) (Miyata et al., 2012), and rice sucrose synthase-1 (RSs-1) (Wang et al., 2005; Dutt et al., 2012). In addition, promoters not originated from plants, such as those from phloem-limited virus genes, including the Coconut foliar decay virus (CFDV) (Hehn \& Rohde, 1998) and the Rice tungro bacilliform virus (RTBV), have also been used as promoters with strong expression in citrus plants (Dutt et al., 2012). The preferential expression of the $\beta$-glucuronidase enzyme in phloem was shown through uidA gene expression in transgenic citrus driven by the AtPP2, CsPP2, AtSUC2, RSs-1, and RTVB promoters (Dutt et al., 2012; Miyata et al., 2012).

The expression of an antimicrobial peptide in the citrus plant phloem, particularly in young leaves, can aid in controlling HLB because this disease is associated with bacteria restricted to phloem cells, which are primarily spread by psyllids while feeding on young leaf phloem (Dutt et al., 2012). Another advantage of preferential expression in phloem is that it decreases the expression of the transgene in other tissues (Zhao et al., 2004).

This work is pioneering in Brazil in relation to quantification by quantitative PCR (qPCR) of gene expression driven by phloem specific promoter in citrus, especially in sweet orange. Although these techniques have already been applied in other studies, the genetic transformation of citrus is a complex issue, since this woody species shows different responses depending on the cultivars and gene constructs used.

The objective of this work was to produce transgenic 'Pêra' and 'Valência' sweet orange plants using the $D 4 E 1$ gene driven by the AtPP2 promoter and to quantify transgene expression in different transformation events.

\section{Materials and Methods}

The study was conducted at the Laboratório de Biotecnologia de Plantas Hortícolas, Escola Superior de Agricultura Luiz de Queiroz, Universidade de São Paulo, SP, Brazil. For the genetic transformation experiments, the strain of $A$. tumefaciens EHA 105 was used, which expressed the binary vector pCAMBIA 2201/D4E1 driven by the AtPP2 promoter and the nopaline synthase (NOS) terminator, as well as the $n p t \mathrm{II}$ gene for kanamycin-resistance selection (Figure 1). 'Pêra' and 'Valência' sweet orange cultivars were selected as the genetic material for the transformation experiments. Seed extraction, explant preparation, transformation, and plant acclimation procedures were carried out according to Miyata et al. (2012).

Plant DNA from the regenerated plants was extracted for PCR analysis using the cetyltrimethylammonium bromide (CTAB) method (Doyle \& Doyle, 1990). The specific primer sequences from the AtPP2 promoter 
to the D4E1 gene were used (AtPP2/D4E1) (Table 1). The samples were amplified in a thermocycler programmed for the following conditions: $94^{\circ} \mathrm{C}$ for $2 \mathrm{~min} ; 40$ cycles at $94^{\circ} \mathrm{C}$ for $30 \mathrm{~s}, 58^{\circ} \mathrm{C}$ for $30 \mathrm{~s}$, and extension at $72^{\circ} \mathrm{C}$ for $30 \mathrm{~s}$; and the reaction was terminated by maintaining the temperature at $72^{\circ} \mathrm{C}$ for $4 \mathrm{~min}$. The amplification product size of $353 \mathrm{bp}$ was assessed through electrophoresis on a $1.5 \%$ agarose gel stained with ethidium bromide $\left(0.03 \mu \mathrm{g} \mathrm{mL}^{-1}\right)$ and photographed under UV light.

Southern blot analysis was performed as described by Southern (2006) to assess whether T-DNA was integrated into the plant genome, using a 275 bp probe with the D4E1 gene and NOS-T terminator (D4E1/ NOS) (Table 1).

RNA extraction from leaves was performed using TRIzol (Life Technologies, Carlsbad, CA, USA) and the extraction protocol recommended by the manufacturer for performing expression analysis using real-time qPCR. Subsequently, the RNA was purified using the RNeasy Plant Mini Kit (Qiagen, Hilden, Germany) followed by a DNase treatment using the RNase-Free DNase Set (Qiagen, Hilden, Germany) according to the manufacturer's instructions. The NanoDrop 2000c spectrophotometer (Thermo Scientific, Wilmington, DE, USA) was used to quantify and assess the RNA. RNA integrity was assessed using $1.5 \%$ agarose gel at $60 \mathrm{~V}$ for $40 \mathrm{~min}$. Reverse transcription was performed in a total volume of $20 \mu \mathrm{L}$, with total RNA $(1 \mu \mathrm{g})$, oligo (dT) primer $\left(10 \mu \mathrm{mol} \mathrm{L}^{-1}\right)$, and Moloney murine leukemia virus (M-MLV) enzyme $(1 \mu \mathrm{L})$. The reaction was carried out according to the manufacturer's instructions (Life Technologies, Carlsbad, CA, USA). The cDNA samples were standardized to $6.6 \mathrm{ng} \mu \mathrm{L}^{-1}$ upon reaction completion and stored at $-20^{\circ} \mathrm{C}$. The relative expression was quantified through real-time qPCR analysis upon cDNA synthesis completion.

Two reference genes, cyclophilin (cyc) and ubiquitin $(u b q)$, were used to analyze gene expression through real-time quantitative PCR and to normalize the D4E1 gene expression levels via specific primers (Table 1). Different concentrations of primers and samples were used to optimize the reaction efficiency. Real-time qPCR analyses were performed in $15 \mu \mathrm{L}$ solution with $5 \mu \mathrm{L}$ of cDNA (30 ng of cDNA), $0.3 \mu \mathrm{L}$ forward and reverse primers, 7.5 $\mu \mathrm{L}$ Fast Sybr Green Master Mix (Life Technologies, Carlsbad, CA, USA), and $1.9 \mu \mathrm{L}$ nuclease-free water. Samples were amplified using three replicates per sample, including samples from non-transgenic plants and a control sample without DNA. The qPCR analyses were performed in a 7500 Fast System (Life Technologies, Carlsbad, CA, USA) using the comparative method and the fast mode in the device's default program. The amplicons were assessed at the end of the reaction through melting analysis, which identifies the average melting point of the amplicons formed during the reaction. The detection of a single dissociation peak for the PCR product strands was regarded as evidence for reaction specificity.

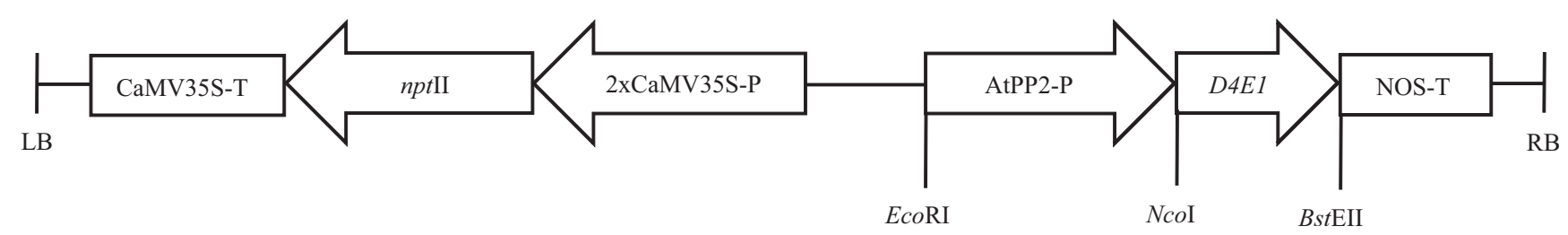

Figure 1. Schematic representation of the T-DNA region in the pCAMBIA2201 vector used for genetic transformation. Gene construct with the nptII selection gene controlled by the CaMV35S promoter and the D4E1 gene controlled by the AtPP2 promoter. LB, left border; RB, right border.

Table 1. Reference and target gene primer sequences and amplicon sizes used in the PCR and qPCR experiments.

\begin{tabular}{lrc}
\hline Gene & Forward/Reverse 5'-3' sequence & Amplicon (bp) \\
\hline AtPP2/D4E1 & CGATAGTTGCTGCCAAAAC/GGTCACCTTACAACTTAATCTTAGC & 353 \\
$D 4 E 1 /$ NOS & CCATGGGATTTAAGTTGAGAG/TTTGCGCGCTATATTTTGTTT & 275 \\
$c y c^{(1)}$ & AGAGTATGCAGAGGAATGG/GTCCTTAACAGAAGTCCGT & 107 \\
$u b q^{(1)}$ & TTCGTCAGTTGACTAATCCT/GTTGCTGTGTTGACTGTG & 95 \\
$D 4 E 1$ & CCATGGGATTTAAGTTGAGAG/GGTCACCTTACAACTTAATCTTAGC & 69 \\
\hline
\end{tabular}

${ }^{(1)}$ Boava et al. (2011). 
The quantification cycle $(\mathrm{Cq})$ value was detected for the target gene and for the two reference genes in each transformation event. The data generated during the qPCR analyses were evaluated to assess efficiency using the LinRegPCR software (Ramakers et al., 2003). This software performs a linear regression for each amplification curve and generates an efficiency value for each reaction, as well as an average efficiency for each gene. After this calculation, the $\mathrm{Cq}$ data produced through qPCR analysis were entered into the GenEx software, version 5.3.6.170 (Kubista et al., 2006), and the average efficiency calculated from LinRegPCR was used to correct the $\mathrm{Cq}$ value for each gene. After correcting the efficiency, the software compared the data using the following relative quantification formula: RQ $=2^{-\Delta \Delta \mathrm{Cq}}$ (Schmittgen \& Livak, 2008). The calibrator was the lowest D4E1-expressing transformant.

\section{Results and Discussion}

The 'Valência' sweet orange explants showed higher bud regeneration and transformation efficiency than those of 'Pêra' sweet orange (Table 2). A similar performance has been observed for 'Pêra' sweet orange in other genetic transformation studies, with lower regeneration and transformation efficiency compared with 'Valência' sweet orange (Boscariol et al., 2003; Fávero et al., 2012). This difference is attributed mainly to the cultivar and to the affinity with A. tumefaciens (Mendes et al., 2002; Almeida et al., 2003; Miyata et al., 2011). Citrus species and cultivars show different responses to genetic transformation.
Therefore, specific protocols must be developed and adapted to each genotype (Donmez et al., 2013).

The AtPP2/D4E1 construct was found in six plants from 'Pêra' sweet orange and in seven plants from 'Valência' sweet orange using PCR analysis (Figure 2). For Southern blot analysis, the transgene copy number in the 'Pêra' sweet orange genome was one for the for the six events, and the integration of two copies in two events and of one copy in the remainder was verified in the 'Valência' sweet orange plants (Figure 3). Noticeably, no event showed gene silencing according to the qPCR analysis results because all transformation events presented gene expression. Gene silencing is typically detected in plants with multiple copies integrated at one or several loci; however, gene silencing was not reported in citrus plants with up to four transgene copies (Dutt et al., 2012; Benyon et al., 2013).

D4E1 gene expression analysis through qPCR showed variable expression, from $\log _{10} 0.76$ to $\log _{10} 1.7$, which corresponds to 5.75 (event 7) and 50 (event 6) times compared with the lowest D4E1-expressing transformant (Figure 4). The different expression

Table 2. Number of explants introduced, bud-regenerating explants, PCR-positive plants, and genetic transformation efficiency for 'Pêra' and 'Valência' sweet oranges using the AtPP2/D4E1 gene construct.

\begin{tabular}{lcccc}
\hline Cultivar & $\begin{array}{c}\text { № of cultivated № of explants } \\
\text { explants }\end{array}$ & $\begin{array}{c}\text { PCR-positive } \\
\text { with buds }\end{array}$ & $\begin{array}{c}\text { Transformation } \\
\text { plants/EP(1) } \\
\text { efficiency (2) }(\%)\end{array}$ \\
\hline 'Pêra' & 939 & 73 & $6 / 9$ & 0.64 \\
'Valência' & 343 & 44 & $6 / 8$ & 1.74 \\
\hline
\end{tabular}

${ }^{(1)} \mathrm{EP}$, evaluated plants. ${ }^{(2)}$ Percentage of PCR-positive plants related to total cultivated explants.

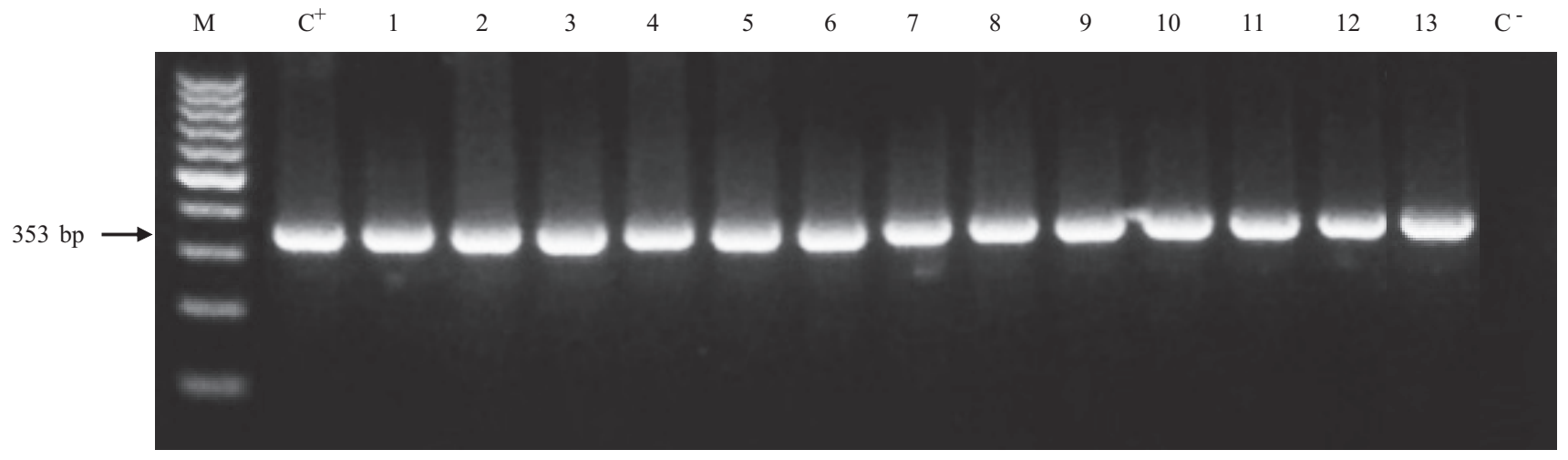

Figure 2. Amplification product from PCR of 'Pêra' (1-6) and 'Valência' (7-13) sweet oranges expressing the AtPP2/D4E1 gene construct. M, GeneRuler 100 bp DNA Ladder (Fermentas, Vilnius, LTU); $\mathrm{C}^{+}$, positive control, reaction with plasmid containing the AtPP2/D4E1 construct; and $\mathrm{C}^{-}$, non-transgenic plant. 
levels are related to the number of copies and to the transgene-insertion position in the genome (Elmayan \& Vaucheret, 1996). The transgene expression values

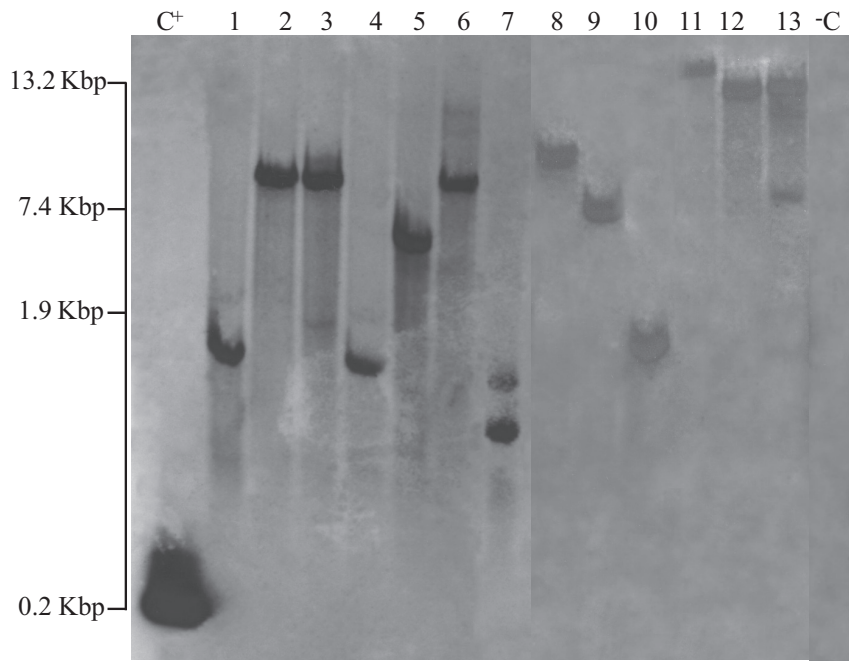

Figure 3. Southern blot analysis for 'Pêra' (1-6) and 'Valência' (7-13) sweet oranges. DNA was digested using the EcoRI enzyme and hybridized with a probe containing an amplicon from the D4E1 gene and NOS terminator. $\mathrm{C}^{+}$, positive control, amplicon with D4E1-NOS amplified through PCR; $\mathrm{C}^{-}$, non-transgenic plant.

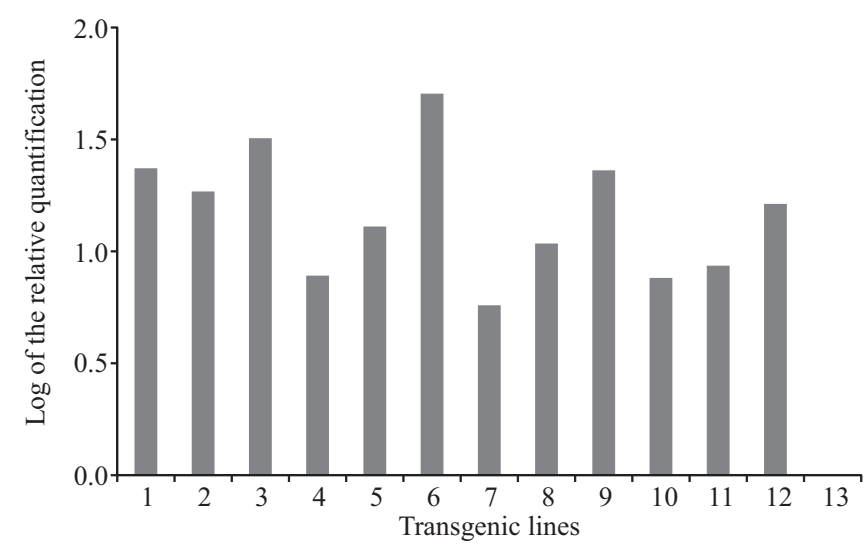

Figure 4. Quantification of relative D4E1 gene expression driven by the AtPP2 promoter, analyzed through real-time PCR. Columns 1-6, transformation events for 'Pêra' sweet orange plants; columns 7-12, transformation events for 'Valência' sweet orange; and column 13, 'Valência' sweet orange transformation event with lowest $D 4 E 1$ expression, used as a calibrator. are similar to those found by Benyon et al. (2013), who observed values from 4.24 to 118.88 , corresponding to $\log _{10} 0.62$ to $\log _{10} 2.07$ for uidA gene expression driven by the AtSUC2 phloem-specific promoter.

Several phloem-specific promoters have been studied for genetic transformation because constitutive transgene expression is unnecessary when localized expression suffices. Miyata et al. (2012) demonstrated specific GUS expression driven by the AtPP2 promoter in phloem tissue of transgenic sweet orange. However, uidA gene expression driven by this type of promoter, quantified by qPCR, is relatively lower when compared to genes driven by constitutive promoters (Dutt et al., 2012; Benyon et al., 2013).

\section{Conclusions}

1. 'Pêra' and 'Valência' sweet oranges can be transformed with the D4E1 gene driven by the AtPP2 promoter.

2. $D 4 E 1$ gene expression levels vary from 5 up to 50 times among different transformation events.

\section{Acknowledgments}

To Centro Avançado de Pesquisa Tecnológica do Agronegócio de Citros Sylvio Moreira, Instituto Agronômico de Campinas (IAC), for providing the fruits for seed extraction; to Fundo de Defesa da Citricultura (Fundecitrus), for financial support; to João Geraldo Brancalion, for his collaboration and computer graphic services; to Coordenação de Aperfeiçoamento de Pessoal de Nível Superior (Capes), for scholarship granted; and to Conselho Nacional de Desenvolvimento Científico e Tecnológico (CNPq), for financial support and for scientific productivity scholarships granted.

\section{References}

ALMEIDA, W.A.B.; MOURÃO FILHO, F.A.A.; PINO, L.E.; BOSCARIOL, R.L.; RODRIGUEZ, A.P.M.; MENDES, B.M.J. Genetic transformation and plant recovery from mature tissues of Citrus sinensis L. Osbeck. Plant Science, v.164, p.203-211, 2003. DOI: 10.1016/S0168-9452(02)00401-6.

BELASQUE JÚNIOR, J.; YAMAMOTO, P.T.; MIRANDA, M.P. de; BASSANEZI, R.B.; AYRES, A.J.; BOVÉ, J.M. Controle do huanglongbing no Estado de São Paulo, Brasil. Citrus Research and Technology, v.31, p.53-64, 2010. DOI: 10.5935/2236-3122.20100005. 
BENYON, L.S.; STOVER, E.; BOWMAN, K.D.; NIEDZ, R.; SHATTERS JUNIOR, R.G.; ZALE, J.; BELNAP, W. GUS expression driven by constitutive and phloem-specific promoters in citrus hybrid US-802. In Vitro Cellular and Developmental Biology - Plant, v.49, p.255-265, 2013. DOI: 10.1007/ s11627-013-9509-9.

BOAVA, L.P.; CRISTOFANI-YALY, M.; MAFRA, V.S.; KUBO, K.; KISHI, L.T.; TAKITA, M.T.; RIBEIRO-ALVES, M.; MACHADO, M.A. Global gene expression of Poncirus trifoliata, Citrus sunki and their hybrids under infection of Phytophthora parasitica. BMC Genomics, v.12, p.12-39, 2011. DOI: 10.1186/1471-2164-12-39.

BOSCARIOL, R.L.; ALMEIDA, W.A.B.; DERBYSHIRE, M.T.V.C.; MOURÃO FILHO, F.A.A.; MENDES, B.M.J. The use of the PMI/mannose selection system to recover transgenic sweet orange plants (Citrus sinensis L. Osbeck). Plant Cell Reports, v.22, p.122-128, 2003. DOI: 10.1007/s00299-003-0654-1.

BOVÉ, J.M. Huanglongbing: a destructive, newly-emerging, century-old disease of citrus. Journal of Plant Pathology, v.88, p.7-37, 2006.

CARY, J.W.; RAJASEKARAN, K.; JAYNES, J.M.; CLEVELAND, T.E. Transgenic expression of a gene encoding a synthetic antimicrobial peptide results in inhibition of fungal growth in vitro and in planta. Plant Science, v.154, p.171-181, 2000. DOI: 10.1016/S0168-9452(00)00189-8.

DE LUCCA, A.J.; BLAND, J.M.; GRIMM, C.; JACKS, T.J.; CARY, J.W.; JAYNE, J.M.; CLEVELAND, T.E.; WALSH, T.J. Fungicidal properties, sterol binding, and proteolytic resistance of the synthetic peptide D4E1. Canadian Journal of Microbiology, v.44, p.514-520, 1998. DOI: 10.1139/w98-032.

DONMEZ, D.; SIMSEK, O.; IZGU, T.; KACAR, Y.A.; MENDI, Y.Y. Genetic transformation in citrus. Scientific World Journal, v.2013, p.1-8, 2013. DOI: 10.1155/2013/491207.

DOYLE, J.J.; DOYLE, J.L. Isolation of plant DNA from fresh tissue. Focus, v.12, p.13-15, 1990.

DUTT, M.; ANANTHAKRISHNAN, G.; JAROMIN, M.K.; BRLANSKY, R.H.; GROSSER, J.W. Evaluation of four phloem-specific promoters in vegetative tissues of transgenic citrus plants. Tree Physiology, v.32, p.83-93, 2012. DOI: 10.1093/ treephys/tpr 130.

ELMAYAN, T.; VAUCHERET, H. Expression of single copies of a strongly expressed 35S transgene can be silenced post-transcriptionally. Plant Journal, v.9, p.787-797, 1996. DOI: 10.1046/j.1365-313X.1996.9060787.x.

FÁVERO, P.; MOURÃO FILHO, F. de A.A.; STIPP, L.C.L.; MENDES, B.M.J. Genetic transformation of three sweet orange cultivars from explants of adult plants. Acta Physiologiae Plantarum, v.34, p.471-477, 2012. DOI: 10.1007/ s11738-011-0843-4.

HEHN, A.; ROHDE, W. Characterization of cis-acting elements affecting strength and phloem specificity of the coconut foliar decay virus promoter. Journal of General Virology, v.79, p.1495-1499, 1998.

KUBISTA, M.; ANDRADE, J.M.; BENGTSSON, M.; FOROOTAN, A.; JONÁK, J.; LIND, K.; SINDELKA, R.;
SJÖBACK, R.; SJÖGREEN, B.; STRÖMBOM, L.; STÅHLBERG, A.; ZORIC, N. The real-time polymerase chain reaction. Molecular Aspects of Medicine, v.27, p.95-125, 2006. DOI: 10.1016/j. mam.2005.12.007.

MACHADO, M.A.; LOCALI-FABRIS, E.C.; DELLA COLETTA-FILHO, H. Candidatus Liberibacter spp., agentes do huanglongbing dos citros. Citrus Research and Technology, v.31, p.25-35, 2010. DOI: 10.5935/2236-3122.20100003.

MENDES, B.M.J.; BOSCARIOL, R.L.; MOURÃO FILHO, F. de A.A.; ALMEIDA, W.A.B. de. Agrobacterium-mediated genetic transformation of 'Hamlin' sweet orange. Pesquisa Agropecuária Brasileira, v.37, p.955-961, 2002. DOI: 10.1590/ S0100-204X2002000700009.

MENTAG, R.; LUCKEVICH, M.; MORENCY, M.J.; SÉGUIN, A. Bacterial disease resistance of transgenic hybrid poplar expressing the synthetic antimicrobial peptide D4E1. Tree Physiology, v.23, p.405-411, 2003. DOI: 10.1093/treephys/23.6.405.

MIYATA, L.Y.; HARAKAVA, R.; STIPP, L.C.L.; MENDES, B.M.J.; APPEZZATO-DA-GLÓRIA, B.; MOURÃO FILHO, F. de A.A. GUS expression in sweet oranges (Citrus sinensis L. Osbeck) driven by three different phloem-specific promoters. Plant Cell Reports, v.31, p.2005-2013, 2012. DOI: 10.1007/ s00299-012-1312-2.

MIYATA, L.Y.; MOURÃO FILHO, F. de A.A.; SCARPARE FILHO, J.A.; ZAMBON, F.; BASSAN, M.M.; MENDES, B.M.J.; HARAKAVA, R. Eficiência de transformação genética de citrange 'carrizo' com duas construções gênicas. Revista Brasileira de Fruticultura, v.33, p.311-315, 2011. DOI: 10.1590/ S0100-29452011005000020.

NEVES, M.F.; TROMBIN, V.G.; MILAN, P.; LOPES, F.F.; CRESSONI, F.; KALAKI, R. Mapeamento da economia citrícola. In: NEVES, M.F. (Ed.). O retrato da citricultura brasileira. Ribeirão Preto: CitrusBR, 2010. p.10-26.

RAJASEKARAN, K.; CARY, J.W.; JAYNES, J.M.; CLEVELAND, T.E. Disease resistance conferred by the expression of a gene encoding a synthetic peptide in transgenic cotton (Gossypium hirsutum L.) plants. Plant Biotechnology Journal, v.3, p.545-554, 2005. DOI: 10.1111/j.1467-7652.2005.00145.x.

RAMAKERS, C.; RUIJTER, J.M.; DEPREZ, R.H.L.; MOORMAN, A.F.M. Assumption-free analysis of quantitative real-time polymerase chain reaction (PCR) data. Neuroscience Letters, v.339, p.62-66, 2003. DOI: 10.1016/S0304-3940(02)01423-4.

SCHMITTGEN, T.D.; LIVAK, K.J. Analyzing real-time PCR data by the comparative C-T method. Nature Protocols, v.3, p.1101-1108, 2008. DOI: 10.1038/nprot.2008.73.

SINGER, S.D.; HILY, J.-M.; COX, K.D. The sucrose synthase-1 promoter from Citrus sinensis directs expression of the b-glucuronidase reporter gene in phloem tissue and in response to wounding in transgenic plants. Planta, v.234, p.623-637, 2011. DOI: $10.1007 / \mathrm{s} 00425-011-1432-x$.

SOUTHERN, E. Southern blotting. Nature Protocols, v.1, p.518-525, 2006. DOI: 10.1038/nprot.2006.73.

STOVER, E.; STANGE JUNIOR, R.R.; MCCOLLUM, T.G.; JAYNES, J.; IREY, M.; MIRKOV, E. Screening antimicrobial 
peptides in vitro for use in developing transgenic citrus resistant to huanglongbing and citrus canker. Journal of the American Society for Horticultural Science, v.138, p.142-148, 2013.

WANG, Z.Y.; ZHANG, K.W.; SUN, X.F.; TANG, K.; ZHANG, J. Enhancement of resistance to aphids by introducing the snowdrop lectin gene gna into maize plants. Journal of Biosciences, v.30, p.627-638, 2005. DOI: 10.1007/BF02703563.

ZHAO, Y.; LIU, Q.Z.; DAVIS, R.E. Transgene expression in strawberries driven by a heterologous phloem-specific promoter. Plant Cell Reports, v.23, p.224-230, 2004. DOI: 10.1007/ s00299-004-0812-0.

Received on February 27, 2013 and accepted on June 28, 2013 